\title{
ANALISIS PERUBAHAN SATURASI OKSIGEN DAN FREKUENSI PERNAFASAN PADA PASIEN DENGAN VENTILATOR YANG DILAKUKAN SUCTION DIRUANG ICU RS MARDI RAHAYU KUDUS
}

\author{
Ari Hana Kristiani ${ }^{*}$, , Suksi Riani' ${ }^{2}$, Mamat Supriyono ${ }^{3}$ \\ ${ }^{1,2}$ STIKes Telogorejo Semarang \\ ${ }^{3}$ Epidemiologi Kesehatan Dinas Kesehatan Kota Semarang \\ *) arihanakristiani3@gmail.com
}

\begin{abstract}
Abstrak
Suction adalah tindakan untuk menjaga kepatenan jalan nafas akibat dari penumpukan sekret yang berlebih, namun tindakan suction selain memiliki manfaat juga memiliki dampak salah satunya perubahan saturasi oksigen dan frekuensi pernafasan. Tujuan dari penelitian ini adalah untuk menganalisis perubahan nilai saturasi oksigen dan frekuensi pernafasan sebelum dan sesudah dilakukan tindakan suction. Metode penelitian ini adalah pre-eksperiment dengan pendekatan one group pre and post test dengan teknik sampling kuota sampling. Populasi pada penelitian ini adalah semua pasien yang terpasang ventilator. Sampel dalam penelitian ini adalah 35 responden. Uji statistik yang digunakan adalah uji paired t-test dan uji wilcoxon. Hasil dari penelitian ini adalah terdapat perubahan yang bermakna untuk nilai saturasi oksigen sebelum dan sesudah dilakukan tindakan suction dengan nilai $p$-value $0,001(<0,05)$, namun tidak terdapat perubahan yang bermakna pada nilai frekuensi pernafasan sebelum dan sesudah dilakukan tindakan suction dengan $p$-value 0,170 (> 0,05). Hasil penelitian ini diharapkan menjadi acuan bagi perawat ICU dalam melakukan suction agar memperhatikan perubahan saturasi oksigen dan frekuensi pernafasan sebelum dan sesudah dilakukan suction.
\end{abstract}

Kata kunci: Suction, saturasi oksigen, frekuensi pernapasan

\begin{abstract}
Suction is an action to maintain airway patency due to excessive secretion accumulation. Suction has both advantages and disavatanges, some of the disavatanges are change of oxygen saturation and respiratory frequency. The study is conducted to analyze the value change of oxygen saturation and respiratory frequency before and after suction. Pre-experiment with one group pre test and post test design was used in the study. There were 35 respondents as the samples. Paired t-test and wilcoxon were applied as the statistical test. The study cloncludes that there is a valuable change of oxygen saturation value, before and after suction with p-value 0,001 $(<0,05)$, but there is no valuable change of respiratory frequency, before and after suction with p-value 0,170 $(<0,05)$. The result of the study can be guidance for nurses of ICU in doing suction to notice change of oxygen saturation and respiratory frequency before and after suction.
\end{abstract}

Keywords: Suction, oxygen saturation, respiratory frequency 


\section{Pendahuluan}

Intensive Care Unit (ICU) merupakan ruangan intensif yang memberikan perawatan kepada pasien dalam kondisi kritis. Ruang ICU memiliki peralatan-peralatan medis yang menunjang dalam memberikan perawatan pada pasien dengan kondisi kritis (Dewi, et al., 2018, hlm.1). Peralatan medis diruang ICU terdiri dari ventilasi mekanik (ventilator), syringe pump, infus pump, defibilator, alat hemodialisa, peralatan drain toraks, echocardiografi dan peralatan suction (Dewi, et al., 2018, hlm.13-14).

Ventilator merupakan alat yang digunakan untuk memberi bantuan dalam proses ventilasi atau pernafasan (Nugroho, Putri \& Putri, 2016, hlm.228). Penggunaan ventilator memberikan efek pada pasien seperti rasa tidak nyaman yaitu adanya penumpukan sekret di Endotrakheal tube (ETT).

Berdasarkan hasil penelitian Bastian (2016, hlm.100) tentang pengalaman pasien yang pernah terpasang ventilator menyatakan bahwa pasien yang terpasang ventilator merasa tidak nyaman karena adanya penumpukan sekret sehingga perlu dilakukan tindakan suction. Selain itu juga pasien merasakan nyeri dan sesak saat tindakan suctionPenggunaan ventilator dalam waktu yang lama menimbulkan banyak kerugian dari segi kesehatan, sosial maupun ekonomi. Dari segi kesehatan penggunaan ventilator yang tidak sesuai akan menimbulkan kerusakan pada paru-paru, pneumothoraks, infeksi hingga kematian (Sundana, 2014, hlm.154). Menurut hasil penelitian (Wahyudi, 2012) menyatakan bahwa sebesar $62,8 \%$ pasien meninggal diantaranya disebabkan karena sepsis $44,4 \%$ dan gagal nafas sebesar $18,5 \%$. Selain itu karena riwayat penggunaan ventilator jumlah pasien yang meninggal relatif tinggi yaitu sebesar $41,8 \%$.

Selain dampak dari segi kesehatan, penggunaan ventilator yang lama akan berdampak pada kehidupan sosial bagi pasien dan keluarga pasien. Dampak sosial timbul akibat dari adanya stressor fisik maupun psikis yang dirasakan keluarga dan pasien berupa perasaan takut menghadapi kematian, perasaan lemah tak berdaya, lingkungan yang asing dan beban biaya yang harus di tanggung (Purnawan \& Saryono, 2010, hlm.55). Hasil penelitian Mardiono (2018, hlm.129-130) menyatakan bahwa keluarga pasien yang di rawat di ruang ICU merasakan bingung, pusing, tidak bisa tidur, takut kehilangan anggota keluarganya, dan merasa pikirannya kacau.

Dampak ekonomi dari penggunaan ventilator dalam kurun waktu yang lama ialah bertambahnya biaya dan beban finansial yang harus di tanggung keluarga. Hal ini dikarenakan biaya perawatan dan sewa alat di ruang ICU yang relatif mahal. Di RS Fatmawati biaya perawatan ICU dengan ventilator per hari mencapai Rp. 1.200.000 belum termasuk dengan biaya sewa alat lainnya. Hasil penelitian Tobing (2013, hlm.8) menyatakan bahwa pada pasien post operasi yang di rawat di ruang ICU akan menghabiskan banyak biaya (high cost) karena banyaknya tindakan dan peralatan yang harus diberikan.

Ventilator memiliki beberapa mode. Mode-mode ventilator terdiri dari controlled mechanical ventilation (CMV), assist control ventilation (ACV), intermittent mandatory ventilation (IMV), dan pressure support ventilation (PSV) (Rab, 2010, hlm.538). Mode PSV merupakan mode ventilator yang diberikan kepada pasien yang sudah mampu bernafas secara spontan atau pasien yang dapat bernafas namun volume tidalnya tidak cukup karena nafas yang dangkal (Nugroho, Putri \& Putri, 2016, hlm.231).

Suction merupakan tindakan untuk menjaga kepatenan jalan nafas dan mencegah terjadinya infeksi bakteri akibat penumpukan sekret yang berlebih di endotrakheal tube (ETT). Manfaat dari suction yaitu menjaga kepatenan jalan nafas (airway), mengurangi risiko Ventilator Assosiated Pneumonia (VAP), mengurangi sekret dan memperlancar proses bernafas (Purnawan \& Saryono, 2010, hlm.49).

Hasil penelitian Kitong (2014, hlm.5) menyatakan bahwa ada perbedaan kadar saturasi oksigen sebelum dan setelah 
dilakukan tindakan suction, ditunjukan dengan adanya penurunan kadar saturasi oksigen dengan selisih nilai $5,174 \%$ dan hasil p-value 0,000. Hasil penelitian yang dilakukan Zukhri (2018, hlm.45) menyatakan bahwa ada perbedaan open suction yang dilakukan sesuai standar prosedur operasional (SOP) di ruang ICU dengan open suction metode Credland terhadap saturasi oksigen perifer pada pasien yang terpasang ventilator dengan $p$-value 0,014 .

Suction dapat menimbulkan perubahan nilai saturasi oksigen dan perubahan frekuensi pernafasan, hal ini terjadi karena saat proses suction oksigen di paru-paru ikut keluar bersama dengan sekret. Perubahan frekuensi pernafasan terjadi sebagai kompensasi dari berkurangnya oksigen yang masuk dalam paru karena proses suction. Perubahan frekuensi pernafasan dapat meningkat atau menurun setelah dilakukan tindakan suction (Nofiyanto, 2013, hlm.133).

Hasil penelitian Nofiyanto (2013, hlm.130) menyatakan bahwa tindakan open suction dapat merubah parameter kardiopulmonal secara signifikan dengan adanya peningkatan heart rate (HR) sebesar 6,412 , peningkatan respiratory rate (RR) sebesar 4,971, penurunan $\mathrm{SpO}_{2}$ sebesar 1,68 dan peningkatan systolic blood pressure (SBP) sebesar 5,71. Hasil penelitian Melastuti (2018, hlm.18-19) menyatakan bahwa kondisi hemodinamika pasien yang dilakukan suction relatif stabil dengan nilai rata-rata tekanan sistol pasien yang dilakukan suction ialah $132,70 \mathrm{mmHg}$, tekanan diastol $78,30 \mathrm{mmHg}$, heart rate (HR) 104,10 $\mathrm{x} / \mathrm{menit}$, respiratory rate (RR) 19,30 x/menit, suhu $36^{\circ} \mathrm{C}, \mathrm{SpO}_{2} 91,7 \%$, MAP 96,80 mmHg.

Hasil studi pendahuluan yang dilakukan di ruang ICU RS Mardi Rahayu Kudus diketahui bahwa pada tahun 2016 terdapat 375 pasien yang terpasang ventilator, tahun 2017 sebanyak 384 pasien, dan pada tahun 2018 sebanyak 475 pasien yang terpasang ventilator. Hasil wawancara dengan 3 orang perawat menyatakan bahwa mode ventilator yang sering digunakan ialah PSIMV. Semua pasien yang terpasang ventilator pasti dilakukan suction. Indikasi dilakukan suction ialah adanya penumpukan sekret, kontraindikasi tidak dilakukan suction jika nilai PEEP > $10 \mathrm{cmH}_{2} \mathrm{O}$. Waktu dalam 1 kali suction tidak boleh $>10$ detik. Perawat sudah melakukan observasi saturasi oksigen dan frekuensi pernafasan sebelum dan sesudah dilakukan tindakan suction. Perawat menyampaikan bahwa prosedur suction meliputi 3A yaitu asionotik (tidak ada tanda tanda sianosis dan penurunan saturasi oksigen), aseptik (melakukan tindakan dengan prinsip aseptik yaitu dengan alat yang steril), atraumatik (tindakan yang dilakukan tidak menimbulkan trauma atau cidera pada saluran pernafasan).

\section{Metode Penelitian}

Penelitian ini merupakan penelitian kuantitatif dengan menggunakan rancangan penelitian pre-eksperimen dengan pendekatan one group pre and post test. Populasi dalam penelitian ini semua pasien yang terpasang ventilator dan dilakukan tindakan suction, rata-rata perbulan 39 orang. Teknik pengambilan sampel pada penelitian ini menggunakan teknik kuota sampling. Jumlah sampel yang diperoleh dalam penelitian ini sebanyak 35 responden. Alat pengumpul data dalam penelitian ini berupa lembar observasi, oxymeter pulse, dan bedside monitor.

Berdasarkan hasil normalitas data diketahui nilai saturasi oksigen sebelum dan sesudah dilakukan suction menggunakan shapiro-wilk didapatkan p-value 0,001 sehingga disimpulkan data tidak berdistribusi normal. Namun hasil normalitas data dengan shapiro-wilk pada nilai frekuensi sebelum dilakukan suction didapatkan p-value 0,090 dan nilai frekuensi pernafasan sesudah dilakukan suction didapatkan p-value 0,217 sehingga disimpulkan data berdistribusi normal. Data nilai saturasi oksigen sebelum dan sesudah dilakukan suction tidak berdistribusi normal maka uji statistik yang digunakan adalah uji wilcoxon sedangkan untuk nilai frekuensi pernafasan sebelum dan sesudah dilakukan tindakan suction data berdistribusi normal maka uji statistik yang digunakan ialah uji paired t-test. 


\section{Hasil dan Pembahasan}

\section{Karakteristik Responden}

Distribusi frekuensi karakteristik responden berdasarkan usia dan jenis kelamin

Tabel 1

Distribusi Frekuensi Karakteristik Responden Berdasarkan Usia dan Jenis Kelamin (n=35)

\begin{tabular}{lcc}
\hline \multicolumn{1}{c}{ Karakteristik } & Frekuensi (f) & Persentase (\%) \\
\hline Usia & & \\
Dewasa Akhir (36-45 tahun) & 9 & 25,7 \\
Lansia Awal (46-55 tahun) & 11 & 31,4 \\
Lansia Akhir (56-65 tahun) & 9 & 25,7 \\
Manula ( $\geq 66$ tahun) & 6 & 17,1 \\
\hline Total & 35 & $100 \%$ \\
\hline Jenis Kelamin & & 40 \\
\hline Laki-laki & 14 & 60 \\
Perempuan & 21 & $100 \%$ \\
\hline Total & 35 &
\end{tabular}

Berdasarkan tabel 1 menunjukkan bahwa karakteristik responden berdasarkan usia mayoritas ialah pada lansia awal sebanyak 11 responden $(31,4 \%)$.

Hasil penelitian ini di dukung oleh penelitian Suryadilaga, Arifin dan Ismail (2015) menyatakan sebanyak 50\% pasien yang dirawat di ruang ICU RSUP Dr.Kariadi berusia 41-60 tahun. Usia lansia awal merupakan keadaan dimana tubuh akan mengalami kemunduran baik dalam kemunduran fungsi tubuh maupun psikis sehingga akan rentan terkena penyakit dan tidak mampu memperbaiki kerusakan yang dialami (Ratnawati, 2017, hlm.19). Salah satu perubahan yang dialami lansia ialah terjadinya perubahan pada sistem pernafasan yaitu terjadinya penurunan elastisitas jaringan paru, atrofi silia, penurunan kekuatan otot pernafasan, dan penurunan tekanan parsial oksigen arteri (Morton, et al., 2011, hlm.197).
Jenis kelamin mayoritas ialah perempuan sebanyak 21 responden (60\%). Hasil penelitian ini didukung dengan penelitian Agustin, et al., (2019) menyatakan bahwa sebagian besar responden berjenis kelamin perempuan $(52,3 \%)$. Selain itu menurut Notoatmodjo (2009, hlm.20) menyatakan bahwa pada perempuan akan mengalami penurunan kadar hormon esterogen yang menyebabkan terjadinya rawan terserang penyakit kronis. 


\section{Gambaran Klinis Responden (mode ventilator dan diagnosa medis)}

Tabel 2

Gambaran Klinis Responden (Mode Ventilator \& Diagnosa Medis) ( $\mathrm{n}=35$ )

\begin{tabular}{lcc}
\hline \multicolumn{1}{c}{ Karakteristik } & Frekuensi (f) & Persentase (\%) \\
\hline Mode Ventilator & & \\
\hline PCMV & 12 & 34,3 \\
PCV & 7 & 20 \\
PSIMV & 14 & 40 \\
Spontan & 2 & 5,7 \\
\hline Total & 35 & $100 \%$ \\
\hline Diagnosa Medis & & \\
\hline Gangguan kardiovaskuler & 6 & 17,1 \\
Gangguan neurologi & 12 & 34,3 \\
Gangguan endokrin & 5 & 14,3 \\
Gangguan respirasi & 1 & 2,9 \\
Gangguan Urologi & 10 & 28,6 \\
Gangguan multiple organ & 1 & 2,9 \\
\hline Total & 35 & $100 \%$ \\
\hline
\end{tabular}

Berdasarkan tabel 2 didapatkan hasil bahwa mode ventilator yang banyak digunakan ialah mode PSIMV sebanyak 14 responden (40\%), hal ini didukung oleh hasil penelitian Melastuti, Wahyuningtyas dan Setyawati $(2018$, hlm.18) menyatakan bahwa sebanyak $100 \%$ dari respondennya menggunakan mode ventilator PSIMV. Mode ventilator PSIMV merupakan mode ventilator yang diberikan kepada pasien yang mempunyai usaha nafas spontan tetapi belum adekuat dan masih tergantung dengan aktivitas pasien (Musliha, 2010, hlm.152).
Sedangkan diagnosa medis mayoritas ialah gangguan neurologi sebanyak 12 responden $(34,3 \%)$. Hasil penelitian ini didukung oleh penelitian Gunawan, Arifin dan Ismail (2015) menyatakan bahwa sebanyak $31 \%$ responden penelitiannya masuk ke ruang ICU karena gangguan neurologi (post craniotomi). Gangguan neurologi merupakan gangguan pada sistem saraf maupun gangguan pada otak sehingga diperlukan perawatan yang intensif (Saputra, 2013, hlm.72).

\section{Perubahan nilai saturasi oksigen sebelum dan sesudah dilakukan tindakan suction}

\section{Tabel 3}

Perubahan nilai saturasi oksigen sebelum dan sesudah dilakukan tindkaan suction $(n=35)$

\begin{tabular}{llccc}
\hline Saturasi oksigen & \multicolumn{1}{c}{ Hasil } & n & Z & p-value \\
\hline Sebelum & Negatif rank & 32 & & \\
Suction & Positif rank & 2 & 4,732 & 0,001 \\
Sesudah & Ties & 1 & & \\
Suction &
\end{tabular}


Berdasarkan tabel 3 menunjukan ada perubahan yang signifikan nilai saturasi oksigen sebelum dan sesudah dilakukan suction dengan nilai $p$-value $0,001(<0,05)$.

Hal ini didukung dengan hasil penelitian Septimar dan Novita (2018) menyatakan bahwa nilai rerata saturasi oksigen sebelum dilakukan suction dan sesudah dilakukan suction pasien kritis di ruang ICU mengalami perubahan yang signifikan dengan $p$-value 0,0001 . Perubahan nilai saturasi oksigen terjadi karena adanya tindakan suction pada selang endotrakheal. Metode suction yang digunakan dalam penelitian ini ialah open suction.
Open suction merupakan salah satu cara suction dengan melepas hubungan selang endotrakheal dan sirkuit ventilator dan kemudian menghisap lendir dengan menggunakan kateter suction (Dewi, 2017, hlm.102). Pelepasan selang endotrakheal dengan sirkuit ventilator pada saat tindakan suction akan mengakibatkan pemutusan suplai oksigen ke paru-paru dan sekaligus akan menghisap udara yang ada didalam paru-paru, hal ini akan berdampak pada penurunan jumlah oksigen yang akan berdifusi dari alveoli ke kapiler paru sehingga akan terlihat adanya penurunan nilai saturasi oksigen (Rab, 2010, hlm.638).

\section{Perubahan nilai frekuensi pernafasan sebelum dan sesudah dilakukan tindakan suction}

\section{Tabel 4}

Perubahan nilai frekuensi pernafasan sebelum dan sesudah dilakukan tindkaan suction $(n=35)$

\begin{tabular}{|c|c|c|c|c|}
\hline $\begin{array}{l}\text { Frekuensi } \\
\text { pernafasan }\end{array}$ & Mean & SD & $\mathbf{t}$ & p-value \\
\hline $\begin{array}{l}\text { Sebelum } \\
\text { suction }\end{array}$ & 20,60 & 4,414 & \multirow[b]{2}{*}{0,543} & \multirow[b]{2}{*}{0,170} \\
\hline $\begin{array}{l}\text { Sesudah } \\
\text { suction }\end{array}$ & 21,14 & 5,214 & & \\
\hline
\end{tabular}

Pada tabel 4 menunjukkan bahwa tidak ada perbedaan yang signifikan nilai frekuensi pernafasan sebelum dan sesudah dilakukan suction dengan p-value $0,170(>0,05)$

Hal ini didukung dengan hasil penelitian Permatasari, Agustin, dan Rahmawati (2017, Ф17) menyatakan bahwa tidak ada perbedaan rerata nilai frekuensi pernafasan pasien kritis yang dilakukan tindakan suction endotracheal tube sebelum dan sesudah diberikan hiperoksigenasi dengan $p$-value 0,173 .

Pada penelitian yang dilakukan peneliti didapatkan hasil bahwa tidak terdapat perubahan yang signifikan nilai frekuensi pernafasan sebelum dan sesudah dilakukan suction, hal ini terjadi karena sebelum dilakukan suction di berikan hiperoksigenasi terlebih dahulu sehingga nilai frekuensi pernafasan sebelum dan sesudah dilakukan suction cenderung stabil.

\section{Simpulan}

Terdapat perubahan yang signifikan nilai saturasi oksigen sebelum dan sesudah dilakukan suction dengan nilai p-value 0,001. Namun pada nilai frekuensi pernafasan sebelum dan sesudah tidak terdapat perubahan yang signifikan dengan nilai $p$ value 0,170 . Sehingga dalam melakukan tindakan suction perlu diperhatikan nilai saturasi oksigen dan frekuensi pernafasan.

Hasil penelitian ini dapat dijadikan salah satu acuan bagi perawat ruang ICU dalam melakukan suction untuk lebih memperhatikan nilai saturasi oksigen dan 
pernafasan sebelum dan sesudah dilakukan tindakan suction. Selain itu hasil penelitian ini diharapkan dapat memberikan informasi dan menambah ilmu pengetahuan kepada mahasiswa khususnya profesi keperawatan dalam mengelola pasien kritis di ruang ICU yang dilakukan tindakan suction. Untuk peneliti selanjutnya dapat dijadikan referensi dalam melakukan penelitian dengan variabel dan metode yang lainnya.

\section{Daftar Pustaka}

Agustin, Wahyu R., et al. (2019). Status Hemodinamik Pasien Yang Terpasang Endotracheal Tube Dengan Pemberian Pre Oksigenasi Sebelum Tindakan Suction Di Ruang Intensive Care Unit, volume 1 Nomor 14.

https://doi.org/10.30787/gaster.v17i1. $\underline{336}$ diperoleh pada tanggal 5 Juli 2019

Andarmoyo, S. (2012). Kebutuhan Dasar Manusia (Oksigenasi): Konsep, Proses, dan Praktik Keperawatan Edisi Pertama. Yogyakarta: Graha Ilmu

Ariani, A.P. (2014). Aplikasi Metodologi Penelitian Kebidanan dan Kesehatan Reproduksi. Yogyakarta: Nuha Medika

Baron, J.F., et al. (2012). Update in intensive care and emergency medicine II: Strategy in bedside hemodynamic monitoring. Berlin: Spinger Scine Media

Bastian, Y. A. F. (2016). Pengalaman Pasien yang Pernah Terpasang Ventilator (The Experience of Patients after using Ventilator), Volume 4 Nomor 1. Jurnal Keperawatan Padjadjaran http://jkp.fkep.unpad.ac.id/index.php/j $\mathrm{kp} /$ article/view/141 diperoleh tanggal 25 Desember 2018

Berman, A., et al. (2009). Buku Ajar Praktik
Keperawatan Klinis. Jakarta: EGC

Brosche, T.A.M. (2012). Buku Saku EKG. Jakarta: EGC

Dewi et al,. (2018). Modul Pelatihan Keperawatan Intensif Dasar Edisi Revisi. Bogor: IN MEDIA

Dharma, K.K. (2011). Metodologi Penelitian Keperawatan

(Pedoman

Melaksanakan dan Menerapkan Hasil Penelitian). Jakarta: TIM

Dickman, A., \& Schneider. (2016). The Syringe driver continous subcutaneous infusions in paliative care 4th edition. United Kingdom: Oxford University Press

Ely, A., et al. (2011). Penuntun Pratikum

Keterampilan Kritis II untuk Mahasiswa D-3 Keperawatan. Jakarta: Salemba Medika

Grap, Mary J, et al. (2010). Effect Of Level Of Lung Injury On HR, MAP, And Sao2 Changes During Suctioning. Intensive And Critical Care Nursing, Volume 10.

https://researchgate.net/291971000 diperoleh tanggal 28 Maret 2019

Gunawan, Vanesha S., Arifin, J., \& Ismail, Akhmad. (2015). Jumlah Pasien Masuk Ruang Perawatan Intensif Berdasrkan Kriteria Prioritas Masuk Di RSUP DR Kariadi Periode JuliSeptember 2014, Volume 4 Nomor 4. Jurnal Media Medika Muda. https://ejournal-

s1.undip.ac.id/index.php/medico diperoleh pada tanggal 5 Juni 2019

Hidayat, A. A. A. (2014). Metode Penelitian Kebidanan dan Teknik Analisa Data: Contoh Aplikasi Studi Kasus. Jakarta: Salemba Medika

- (2017). Metodologi Penelitian Keperawatan dan Kesehatan. Jakarta: Salemba Medika 
Hudak, C.M \& Gallo, B.M. (2010). Keperawatan Kritis pendekatan Holistik. Jakarta: EGC

Jevon, Philip. (2009). Pemantauan Pasien Kritis seri keterampilan klinis esensial untuk perawat Edisi Kedua. Jakarta: Erlangga

Jongerden, I. P., Kesecioglu, J., Speelberg, B., Buiting, A. G., Leverstein-van Hall, M. A., \& Bonten, M. J. (2012). Changes in heart rate, mean arterial pressure, and oxygen saturation after open and closed endotracheal suctioning: $\quad A$ prospective observational study. Journal of Critical Care. https://doi.org/10.1016/j.jcrc.2012.02 .016 diperoleh tanggal 1 Desember 2018

Kartikawati, D. (2011). Buku Ajar DasarDasar Keperawatan Gawat Darurat. Jakarta: Salemba Medika

Kepmenkes RI. (2010). Keputusan Menteri Kesehatan Republik Indonesia Nomor 1778/MENKES/SK/XII/2010 Tentang Pedoman Penyelenggaraan Pelayanan Intensive Care Unit (ICU) di Rumah Sakit. https://perdici.org/guidelines/ diperoleh pada tanggal 17 Januari 2019

Keykha, A., et al. (2016). Comparing the effects of suction and routine methods on vital sign, arterial blood oxygen saturation and pain level of patients hospitalized at the intensive care unit. Journal of critical care nursing in press. https://doi.org/10.17795/ccn6619 diperoleh pada tanggal 23 Februari 2019

Kitong, B. I., Mulyadi, N., \& Malara, R. (2014). Pengaruh Tindakan Penghisapan Lendir Endotrakeal
Tube (ETT) Terhadap Kadar Saturasi Oksigen Pada Pasien Yang Dirawat Di Ruang Icu Rsup Prof. Dr. R. D. Kandou Manado. Jurnal Keperawatan indonesia. https://ejournal.unsrat.ac.id/index.php /jkp/article/view/5275_diperoleh tanggal 3 November 2018

Kozier, B., et al. (2009). Buku Ajar Praktik Keperawatan Klinis Edisi 5 penerbit Buku Kedokteran. Jakarta: EGC

Kozier, B., et al. (2010). Buku Ajar Fundamental Keperawatan: Konsep, Proses, dan Praktik Edisi 7. Jakarta: EGC

Lesmana, H. (2015). Analisis dampak penggunaan varian tekanan suction terhadap pasien cedera kepala berat, Volume 3 Nomor 3. Jurnal Keperawatan Padjadjaran. http://jkp.fkep.unpad.ac.id/index.php/j $\mathrm{kp} / \mathrm{article} / \mathrm{view} / 114$ diperoleh pada tanggal 22 Desember 2018

Lopes, F. M., \& Lopez, M. F. (2009). Impact of the open and closed tracheal suctioning system on the incidence of mechanical ventilation- associated pneumonia: literature review. Brazilian Association of Intensive Care Medicine, Volume 21. http://www.scielo.br/scielo.php?pid= S0103507X2009000100012\&script $=\mathrm{s}$ ci_arttext\&tlng=es diperoleh pada tanggal 23 Februari 2019

Loscalzo, J. E. (2016). Harrison Pulmonologi dan Penyakit Kritis Edisi 2. Jakarta: EGC

Lynn, P. (2010). Taylor's Handbook of clinical nursing skill. Philadelphia: Wolters Kluwer

Maggiore, S.M. et al,. (2013). Decreasing the adverse effects of endotracheal suctioning during mechanical 
ventilation by changing practice.

Countinuing Respiratory Care

Education, Volume 58.

https://www.ncbi.nlm.nih.gov/pubme

d/23466423 diperoleh pada tanggal

22 Februari 2019

Mardiono, S. (2018). Tingkat Kecemasan Keluarga terhadap Perubahan Status Kesehatan pada pasien kritis diruang rawat inap intensif care unit (ICU) Rumah Sakit Pelabuhan Palembang tahun 2017, Volume 2. Jurnal 'Aisyiyah Medika. https://jurnal.stikes-aisyiyahpalembang.ac.id/index.php/JAM/artic le/view/79 diperoleh tanggal 4 Januari 2019

Marlisa., I.S.P., \& Kosasih, C,. (2013). Efek Suction melalui Catheter Mouth terhadap Saturasi Oksigen pada Pasien Cedera Kepala, Vol. 1 Nomor 3.

https://doi.org/10.1177/10755470145 25350 diperoleh tanggal 1 Desember 2018

Melastuti, E., Wahyuningtyas, W., \& Setyawati, R. (2018). Gambaran Hemodinamik Pasien Yang Dilakukan Open Suction System Description of Hemodynamic Patients Doing Open Suction System.

https://jurnal.unissula.ac.id/index.php/ unc/article/download/2861/2078 diperoleh tanggal 5 Januari 2019

Morton, Patricia G., et al. (2011). Keperawatan Kritis Pendekatan Asuhan Holistik Volume 1. Jakarta:EGC

Musliha. (2010). Keperawatan Gawat Darurat. Jakarta: NuMed

Nasir, Abd., Muhith, A., \& Ideputri, M.E. (2011). Buku Ajar Metodologi Penelitian Kesehatan: Konsep
Pembuatan Karya Tulis dan Thesis untuk Mahasiswa Kesehatan. Yogyakarta: Nuha Medika

Nizar, Afif M., \& Haryati, Dwi S. (2017). Pengaruh suction terhadap kadar saturasi oksigen pada pasien koma di ruang ICU RSUD Dr. Moewardi Surakarta tahun 2015, Volume 3 Nomor 2. Jurnal Poltekkes Solo. https://jurnal.poltekkessolo.ac.id/index.php/JKG/article/dow nload/351.313 diperoleh tanggal 2 Juni 2019

Nofiyanto, M. (2013). Perbedaan Parameter Kardiopulmonal Setelah Tindakan Open Suction, Volume 2 Nomor 3. Jurnal Media Ilmu Kesehatan. http://ejournal.unjaya.ac.id/index.php/ mik/article/view/113 diperoleh tanggal 26 Desember 2018

Notoadmodjo. (2009). Kesehatan Masyarakat Ilmu dan Seni. Jakarta: Rineka Cipta

Notoatmodjo, S. (2012). Metodologi Penelitian Kesehatan. Jakarta: Rineka Cipta

Nugroho, T., Putri, B.T., Putri, D.K. (2016). Teori Asuhan Keperawatan Gawat Darurat. Yogyakarta: Nuha Medika

Nursalam. (2013). Metodologi Penelitian Ilmu Keperawatan: Pendekatan Praktis Edisi 3. Jakarta: Salemba Medika

Nuryadi, et al. (2017). Dasar-dasar Statistik Penelitian. Yogyakarta: Gramasurya

Potter, P.A. \& Perry, A.G. (2009). Fundamental Keperawatan Edisi 7 Buku 2. Jakarta: Salemba Medika

Potter, P.A. \& Perry, A.G. (2010). Fundamental Keperawatan Volume 1 Edisi 7. Jakarta: Salemba Medika

Purnawan, I., \& Saryono. (2010). Mengelola Pasien Dengan Ventilator Mekanik. 
Jakarta: Rekatama

Rab, T. (2010). Ilmu Penyakit Paru. Jakarta: TIM

Ratnawati, Emmelia. (2017). Asuhan Keperawatan Gerontik. Yogyakarta:PT.Pustaka Baru

Rosdahl, C.B. (2014). Buku Ajar Keperawatan Dasar Edisi 10 Volume 4. Jakarta: EGC

Rosyida, N.I.P. (2011). Hubungan Metode Suction Pada Pasien Terpasang Ventilator Terkait Kejadian Infeksi Nosokomial Ventilator-Associated Pneumonia (VAP) Tahun 2007 Sampai Tahun 2010 (Studi di Rumah Sakit " $X$ " Surabaya). Perpustakaan Universitas Airlangga. http://repository.unair.ac.id/23058/1/g dlhub-gdl-s1-2011-rosyidanur-20749fkm171-k.pdf di peroleh pada tanggal 26 Februari 2019

Saputra, Lyndon. (2013). Buku Saku Horrison Kedaruratan Medik Disertai Contoh Kasus Klinik. Tangerang Selatan: Karisma Publishing Group Saryono. (2010). Catatan Kuliah Kebutuhan Dasar Manusia (KDM). Yogyakarta: Nuha Medika

Saskatoon Health Region Authority (SHRA). (2010). Suctioning artificial airways in adults tracheostomy and endotracheal tubes $R N \& G N$ Learning Package. http://www.saskatoonhealthregion.ca/ diperoleh pada tanggal 17 Februari 2019

Sastroasmoro, S. (2014). Dasar-dasar Metodologi Penelitian Klinis. Jakarta: Sagung Seto

Septimar, Z. M., \& Novita, A. R. (2017). Pengaruh Tindakan Penghisapan Lendir (Suction) terhadap Perubahan Kadar Saturasi Oksigen pada Pasien kritis di ICU, Volume 3 Nomor 22. Jurnal Ilmu Kesehatan Masyarakat. http://journals.stikim.ac.id/ojs_new/in dex.php/jikm/article/download/47/39/ diperoleh tanggal 4 Desember 2018

Setiadi. (2013). Konsep dan Praktik Penulisan Riset Keperawatan.Yogyakarta: Graha Ilmu

Somantri, I. (2009). Asuhan Keperawatan pada pasien dengan gangguan sistem pernafasan. Jakarta: Salemba Medika

Stevani, Priscila. 2016. Pengaruh Hormon Wanita pada Penyakit. http://rspremiersurabaya.com/pengaruhhormon-wanita-pada-penyakit. Diperoleh pada tanggal 12 Juni 2019

Stillwell, S.B. (2011). Pedoman Keperawatan Kritis Edisi 3. Jakarta: EGC

Sugiyono. (2014). Metode Penelitian Kuantitatif, Kualitatif dan $R \& D$. Bandung: Alfabeta

Sundana, K. (2014). Ventilator pendekatan praktis di unit perawatan kritis volume 1 edisi revisi. Jakarta: CICU

Suryadilaga, Y., Arifin, J \& Ismail, A. (2015). Jumlah Kematian pasien di ruang perawatann intensif berdasarkan kriteria prioritas masuk RSUP Dr.Kariadi periode JuliDesember 2014, Volume 4 nomor 4. Jurnal Media Medika Muda. https://ejournals1.undip.ac.id/index.php/medico diperoleh pada tanggal 5 Juni 2019

Susilowarno, R., et al. (2017). Buku Ajar Biologi untuk siswa SMA Kelas XII. Jakarta: Grasindo

Swarjana, I. K. (2015). Metodologi Penelitian Kesehatan. Yogyakarta: ANDI Publ

Tobing, A.S.M.L. (2013). Analisis Hubungan 
Biaya Perawatan dan Hasil

Perawatan Pasien Surgikal di ruang rawat Intensif ICU (studi analitik di ruang rawat intensif ICU RSUP $d r . K a r i a d i$ Semarang), Volume 2 Nomor 1. Jurnal Kedokteran Diponegoro.

https://ejournal3.undip.ac.id/index.ph p/medico/article/view/4885 diperoleh pada tanggal 10 Januari 2019

Wahyudi, I. E. D. (2012). Angka Kematian Pasien End Stage Renal Disease di ICU dan HCU RSUP Dr. Kariadi, Volume 1 Nomor 1 . Jurnal Kedokteran Diponegoro. https://ejournal3.undip.ac.id/index.ph p/medico/article/view/1752 diperoleh tanggal 17 Desember 2018

Wahyuningsih, Indah S. (2017). Profil Demografi Pasien Kritis Dewasa Berventilator Yang Mengalami Nyeri, Volume 7 Nomor 3. Jurnal Keperawatan Dan Pemikiran Ilmiah NURSCOPE.

https://jurnal.unissula.ac.id/index.php/ jnm/article/view/1665/1265 